\title{
Repression by the yeast meiotic inhibitor RME1
}

\author{
Peter A. Covitz ${ }^{1}$ and Aaron P. Mitchell ${ }^{1-3}$ \\ ${ }^{1}$ Department of Microbiology and ${ }^{2}$ Institute of Cancer Research, College of Physicians and Surgeons, Columbia University, \\ New York, New York 10032 USA
}

\begin{abstract}
The RME1 gene product, a negative regulator of meiosis with three zinc finger motifs, acts by preventing transcript accumulation from IME1, whose product is required for meiotic gene expression. We have isolated a 404-bp segment from a region $2 \mathrm{~kb}$ upstream of IME1 that is sufficient for RME1-dependent repression of a heterologous promoter. This DNA contains an RME1-response element (RRE) and another region called the modulation region. The modulation region is required for repression because DNA containing the RRE alone did not repress but was able to confer RME1-dependent transcriptional activation of a reporter gene. In gel mobility retardation assays, RME1 formed a specific complex with the RRE, and RRE point mutations that reduced the affinity for RME1 also blocked repression and activation. Footprinting of the RME1-RRE complex revealed a 21-bp protected region that included the positions of these RRE mutations. We conclude that RME1 binding to this RRE is required for repression. Thus, the mechanism of meiotic inhibition by RME1 is direct transcriptional repression of IME1.
\end{abstract}

[Key Words: S. cerevisiae; transcriptional repression and activation; RME1; meiosis; sporulation]

Received April 7, 1993; revised version accepted May 26, 1993.

Transcriptional repressors that are sequence-specific DNA-binding proteins can be distinguished by the position or context of their binding sites. For example, $\alpha 2-$ MCM1, al $-\alpha 2$, and ROX1 of yeast repress promoters lying within $300 \mathrm{bp}$ of their binding sites (Johnson and Herskowitz 1985; Goutte and Johnson 1988; Keleher et al. 1988; Herskowitz 1989; Zitomer and Lowry 1992). These proteins may repress by recruiting a global negative regulatory complex, such as SSN6-TUP1 (Zhang et al. 1991; Keleher et al. 1992) or by positioning nucleosomes such that essential promoter sites are occluded (Shimizu et al. 1991; Roth et al. 1992). Other proteins, such as RAP1 of yeast, have different properties. RAP1 acts as a positive regulator through an isolated binding site (Brand et al. 1987; Shore and Nasmyth 1987). When the binding site is within a region called a silencer, however, RAP1 acts to repress target promoters $>1000 \mathrm{bp}$ away (Shore and Nasmyth 1987; Sussel and Shore 1991). Repression appears to require that RAPl and other silencer-binding factors, such as ABF-1, establish or maintain an altered chromatin state that is inaccessible to RNA polymerases, endonucleases, and methylases (Nasmyth 1982; Strathern et al. 1982; Schnell and Rine 1986; Shore and Nasmyth 1987; Shore et al. 1987; Buchman et al. 1988; Kayne et al. 1988; Singh and Klar 1992).

Our studies focus on the yeast RME1 protein, a zinc finger protein homolog that inhibits meiosis and spore formation (Kassir and Simchen 1976; Mitchell and Her-

${ }^{3}$ Corresponding author. skowitz 1986; Covitz et al. 1991). RME1 is expressed in a and $\alpha$ cells, which are thus unable to enter meiosis, and is repressed in a/ $\alpha$ cells, which can enter meiosis in response to starvation (Mitchell and Herskowitz 1986). Genetic and molecular studies indicate that RME1 exerts its effects by blocking transcript accumulation from the IME1 gene (Kassir et al. 1988; Covitz et al. 1991). The $I M E 1$ product is required for expression of IME2 and many other meiotic genes (Engebrecht and Roeder 1990; Mitchell et al. 1990; Smith et al. 1990). There are several positive regulators of IME1 that, in principle, might be more direct targets of repression by RMEl (Neigeborn and Mitchell 1991; Shah and Clancy 1992; Su and Mitchell 1993). So far, none of those genes appears to be regulated by RME1. These findings are consistent with the notion that RME1 represses IME1 more directly.

Here, we report that RMEl binds specifically to a site $2 \mathrm{~kb}$ upstream of the IME1 gene and that the RME1 binding site is required for full repression of IME1. RME1 can either repress or activate transcription of a reporter gene, depending on the context of its binding site. Our results indicate that RME1 is a new example of a transcription factor capable of effecting either negative or positive regulation. Further, the context of the RMEl-binding site is key in determining which activity will be manifested.

\section{Results}

\section{Isolation of an RME1-dependent repression cassette}

To identify a region involved in cell-type control of $I M E 1$ 
expression, we performed a deletion analysis of a plasmid-borne IME1 gene. We compared sporulation in a/a and $\mathbf{a} / \alpha$ diploids to monitor the response of plasmid deletion derivatives to cell type signals (Fig. 1). a/a diploids are unable to sporulate in part because they express $R M E 1$, which in turn represses IME1. We reasoned that a properly regulated IME1 gene would not stimulate sporulation of a/a strains but that deletions permitting IME1 expression would result in higher levels of sporulation. As a control, we tested the ability of each plasmid to stimulate sporulation in an a/ $\alpha$ ime $1 \Delta /$ ime $1 \Delta$ strain. Sporulation of this strain confirmed that each IME1 derivative was expressed in the absence of RME1, which is transcriptionally repressed in a/ $\alpha$ cells. Plasmids containing $5^{\prime}$ deletion end points between -5600 and -2243 appeared to be properly regulated by cell-type signals: They permitted much lower levels of sporulation in the a/a diploid than in the $\mathbf{a} / \alpha$ control strain (Fig. 1, pAC55-2, pAC58, pAC67, pAC70, and pAC82; the basal level of sporulation of the a/a strain bearing these plasmids may reflect the increased IME1 gene dosage). Plasmids with deletion end points from -2001 to -1202 , however, had elevated levels of IME1 expression in the a/a strain: They stimulated more similar levels of sporulation in the $\mathbf{a} / \mathbf{a}$ and $\mathbf{a} / \alpha$ diploids (Fig. 1, pAC85-26, pAC62, and pAC59|. An internal deletion that eliminated sequences from -1954 to -1203 also permitted elevated levels of $I M E 1$ expression in the a/a strain (Fig.
1, pAC87-2), whereas a deletion from -1742 to -1119 did not (Fig. 1, pACl64). We delineated the $5^{\prime}$ border of the region that influences $I M E 1$ expression, -2243 , by comparing the end points of pAC82 and pAC85-26. The 3 ' border, -1743 , was delineated by comparing the end points of pAC87-2 and pAC164.

The deletions in this $501 \mathrm{bp}$ upstream region may have either eliminated a cis-acting regulatory sequence or affected a gene encoding a trans-acting factor. The ability of the deletion derivatives to stimulate sporulation of either the a/a test strain or the a/ $\alpha$ control strain required the presence of an intact IME1-coding sequence (Fig. 1, pAC72 and pAC73). In addition, we found no long open reading frame between -2243 and the IME1-coding region ( $\leqslant 74$ codons), indicating that there is no neighboring protein-coding sequence that might be affected. We conclude that the $501 \mathrm{bp}$ upstream regulatory region from -2243 to -1743 acts in cis to IME1.

Deletions of the upstream regulatory region may have abolished repression by a cell-type control pathway. Alternatively, such deletions may have caused a general increase in IME1 expression. We distinguished between these two possibilities by direct measurement of $I M E 1$ RNA expression from pAC82, which contains the upstream regulatory region, and pAC85-26, which has a deletion in this region (see Fig. 1). To focus on the effects of RME1 alone, we compared IME1 transcript levels in a/ $\alpha$ ime1/ime1 strains that differed in their expression of

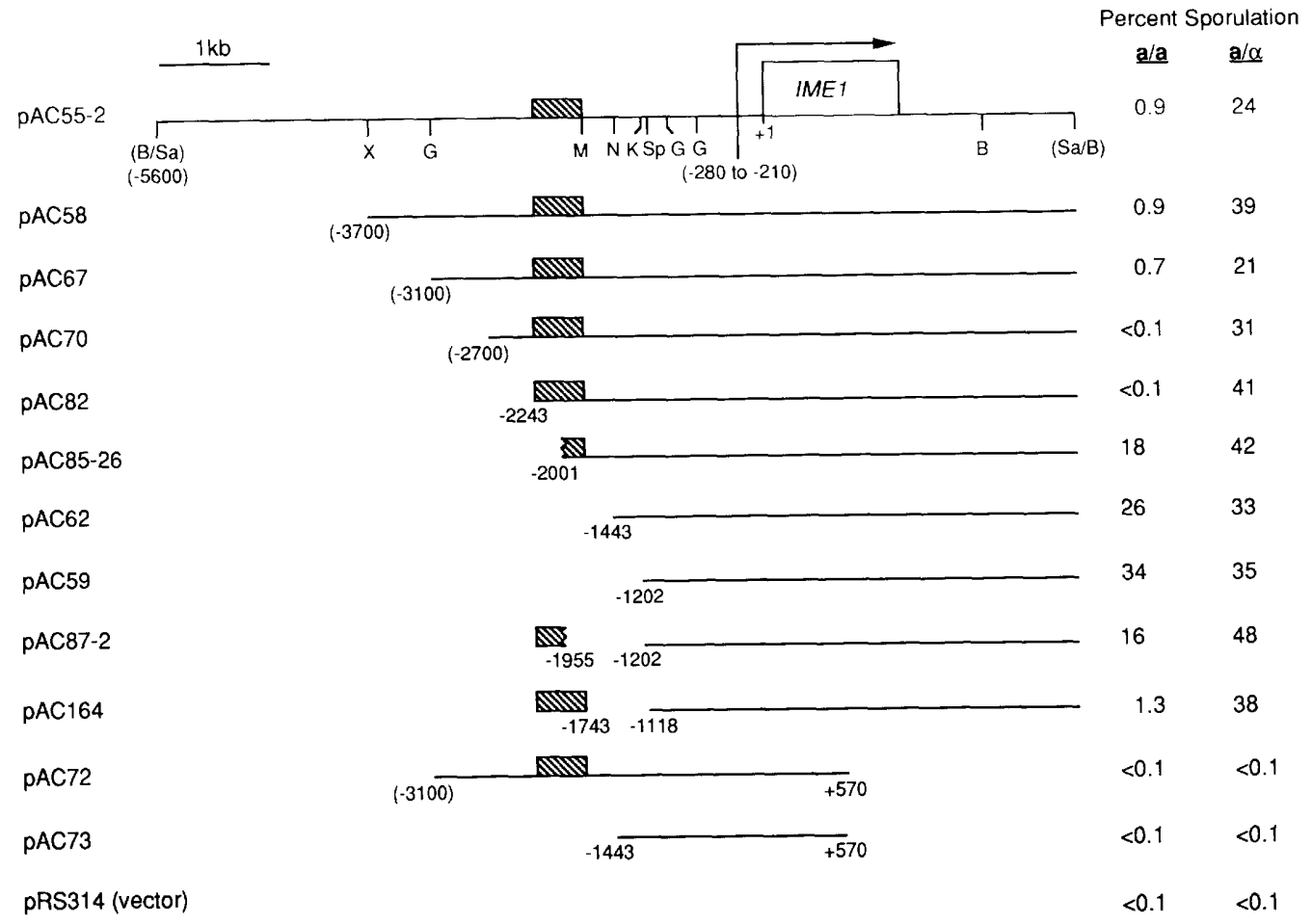

Figure 1. Sporulation assay for plasmid $I M E 1$ expression. a/a and a/ $\alpha$ ime1/ime 1 diploids bearing each plasmid were incubated on sporulation medium for 3 days, and the percent sporulation was determined. The hatched box represents the upstream regulatory region. Deletion end points are numbered with respect to the IME1 initiation codon (+1). The IME1 RNA start sites lie between -210 and -280 (Smith et al. 1990; Sherman et al. 1993). End points in parentheses are approximate. The strains used were 931 and $805 / 808$. Restriction sites are (B) BamHI; (Sa) Sau3A; (X) XhoI; (G) BgIII; (N) NheI; (M) MscI; (K) KpnI; (Sp) SphI. 


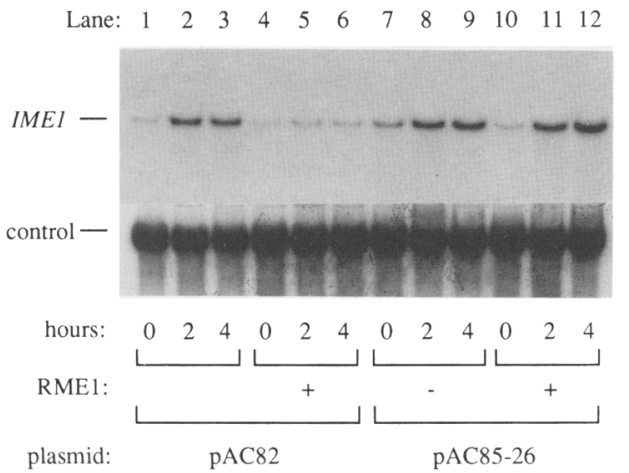

Figure 2. Effect of RME1 on IME1 expression from plasmid deletion derivatives. RNA was prepared 0,2 , or $4 \mathrm{hr}$ after starvation from a/ $\alpha$ strains bearing the $I M E 1$ plasmid deletion derivative pAC82 (lanes 1-6) or pAC85-26 (lanes 7-12). RME1 expression was regulated from $P_{G A L 1}$ : RMEl not expressed $[1-1$ lanes 1-3 and 7-9], or expressed $[(+\mid$ lanes $4-6$ and 10-12]. The strains were $1049 / 1053$ and $1050 / 1051$.

RME1 from the GAL1 promoter (Fig. 2). The $P_{G A L 1}-$ $R M E 1$ gene was regulated independently of cell type by use of wild-type or null alleles of $G A L 80$, a negative regulator of the GAL1 promoter. IME1 expression from both pAC82 and pAC85-26 increased upon starvation in cells lacking RME1 (Fig. 2, lanes 1-3,7-9). RME1 blocked this increase from pAC82 (Fig. 2, cf. lanes 1-3 and 4-6). In contrast, RME1 had no effect on IME1 expression from pAC85-26 (Fig. 2, cf. lanes 7-9 and 10-12). We conclude that the upstream regulatory region is required for repression of the plasmid-borne IME1 gene by RME1. This region does not appear to have a role in the nutritional control of IME1 transcription.

To determine whether this region is sufficient for RME1-dependent repression, we examined its effect on the heterologous $C Y C 1$ promoter. [The separable upstream activating sequences (UASs) in the CYC1 promoter (Guarente and Mason 1983) are here referred to collectively as UAS $\mathrm{UYC1}_{\mathrm{C} 1}$. We placed the 501-bp regulatory segment $(-2243$ to -1743$)$ upstream of $U_{A S} S_{C Y C 1}$ in the $c y c 1-1 a c Z$ reporter plasmid pKB112 and measured $\beta$-galactosidase activity in a strain expressing RMEl and in a control strain expressing RME1-213, a nonfunctional missense derivative (Covitz et al. 1991). The upstream regulatory region repressed $\mathrm{UAS}_{C Y C 1} 17$-fold in the strain expressing RME1 but not in the control strain (Fig. 3, pAC137-4). This value is in good agreement with estimates of 6- to 30-fold repression of chromosomal IME1 RNA levels by RMEl (Kassir et al. 1988; Smith and Mitchell 1989). We defined more narrowly the DNA responsible for RME1-dependent repression by constructing deletion derivatives and assaying RMEl-dependent repression of $\mathrm{UAS}_{\mathrm{CYC1}}$ (Fig. 3). A deletion that left the $404 \mathrm{bp}$ from -2146 to -1743 was sufficient to give 27 fold repression (Fig. 3, pAC153-4). A fragment containing an internal deletion from -2016 to -1976 still gave over sixfold repression (Fig. 3, pAC157-2). The remaining sequences, -2146 to -2017 and -1975 to -1743 , were required for repression (Fig. 3, pAC160-2, pAC152-3, pAC141-10, and pAC142-10). These data establish that the $404 \mathrm{bp}$ fragment from -2146 to -1743 is sufficient for repression by RME1. The sequence of this DNA, which we call the repression cassette, is shown in Figure 4 .

\section{Identification of an RME1-response element}

The above analyses and further experimentation indicated that the repression cassette can be divided into two distinct segments. Each is required for RMEl-dependent repression. The first segment, -2146 to -2017 , contains an RME1-response element (RRE), the evidence for which is described below. The other segment, -1975 to -1743 , is referred to as the modulation region. A chance observation enabled us to identify the segment containing the RRE. We noticed that the repression cassette stimulated gene expression when transferred into the
Figure 3. RMEl-dependent repression of the CYC1 promoter. pKB112 contains UAS $_{C Y C 1}$ fused to a lacZ reporter gene (not to scale). Derivatives contain insertions from the IME1 upstream regulatory region; end points are numbered with respect to the IME1 initiation codon. Strains that expressed RME1 or RME1-213 and contained these plasmids were assayed for $\beta$-galactosidase activity. The hatched box indicates the RRE; the stippled box indicates the modulation region. The strains were 1122 and 1124 .

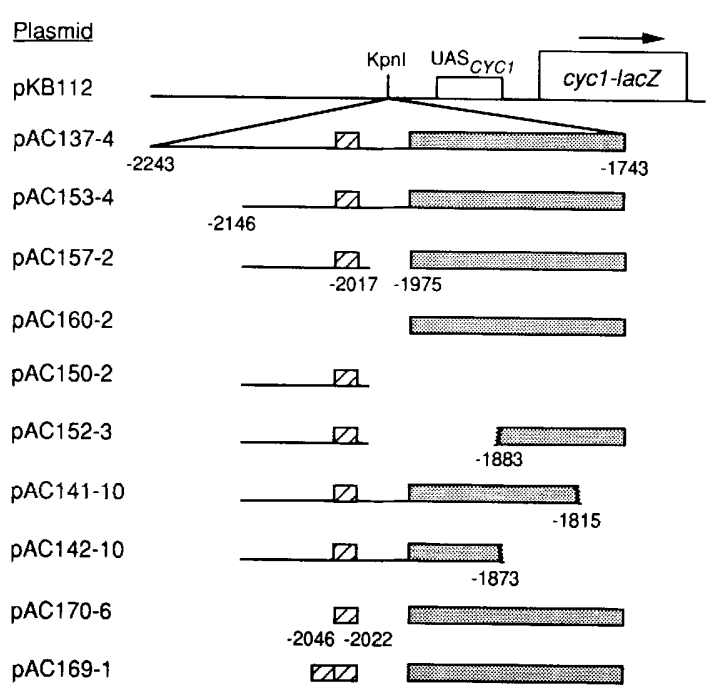

\begin{tabular}{|c|c|c|}
\hline \multicolumn{2}{|c|}{ B-gal units } & Fold \\
\hline BME1 & RME1-213 & Repression \\
\hline 2740 & 3230 & 1.2 \\
\hline 255 & 4230 & 17 \\
\hline 134 & 3640 & 27 \\
\hline 640 & 4120 & 6.4 \\
\hline 2690 & 3190 & 1.2 \\
\hline 4170 & 4400 & 1.1 \\
\hline 3010 & 3090 & 1.0 \\
\hline 1540 & 3200 & 2.1 \\
\hline 3400 & 3180 & 0.9 \\
\hline 759 & 3720 & 4.9 \\
\hline & 3210 & 5.4 \\
\hline
\end{tabular}


-2146 GGTGTTGGAGTAATTTGATTAATGTATTCCCtCACGGAGGTTCAGTAGATATTCTCAATAAAAGAAGgGTGGGGGTGTAT

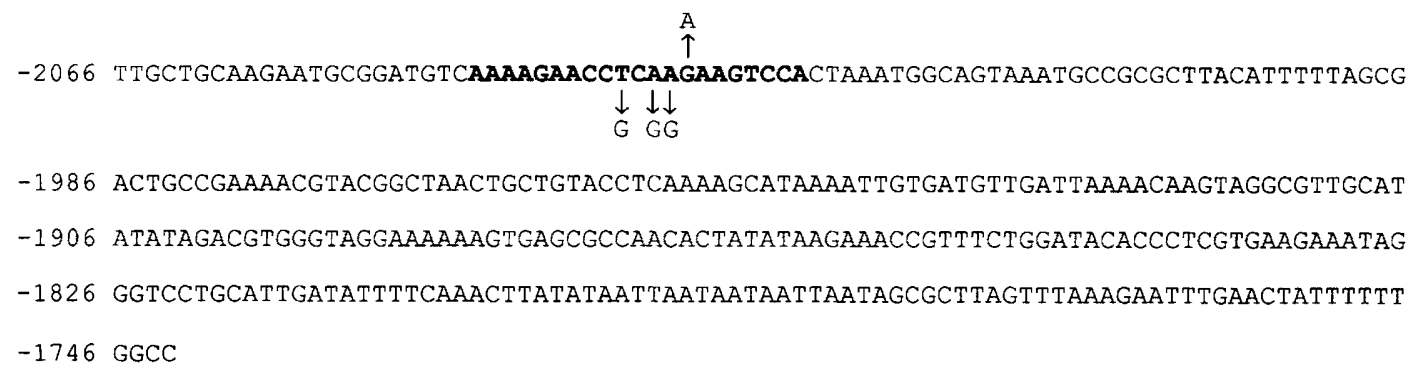

Figure 4. Sequence of the repression cassette. The RRE $\downarrow$ mutations are indicated below their position, the RRE $\uparrow$ mutation is indicated above its position (see Tables 1 and 2). -2044 to -2024 , the region in the RMEl-DNA complex protected from chemical nuclease scission, is shown in boldface type (see Fig. 8).

cyc1-lacZ reporter plasmid pLG 312 S $\Delta S S$, which lacks $\mathrm{UAS}_{C Y C 1}$, and that activation was RME1 dependent (Fig. 5, cf. pLG $\Delta 312 S \Delta S S$ and pAC155-2). Expression was 5- to 10 -fold higher when the modulation region was removed (Fig. 5, cf. pAC155-2 with pAC106-4 and pAC110-6). Further deletions indicated that the $130 \mathrm{bp}$ from -2146 to -2017 contained the DNA required for RME1-dependent activation (Fig. 5, pAC110-6), suggesting that an RRE lay within this sequence. The region from -2146 to -2017 alone was sufficient for activation (Fig. 5), but both this segment and the modulation region were required for repression (Fig. 3).

We conducted a mutational analysis to identify specific base pairs involved in RME1-dependent activation. Mutant fragments containing the sequence from -2146 to -2017 were generated and transferred into a $c y c 1-$ $l a c Z$ reporter vector that lacked $\mathrm{UAS}_{C Y C 1}$ (see Materials and methods). This analysis identified two classes of RRE mutations. The first includes three mutations that eliminated RME1-dependent activation (Table 1). These were designated RRE $\downarrow 1, R R E \downarrow 2$, and RRE $\downarrow 3$ and corresponded to the base changes $-2035^{\mathrm{T} \rightarrow \mathrm{G}},-2033^{\mathrm{A} \rightarrow \mathrm{G}}$, and $-2032^{\mathrm{A} \rightarrow \mathrm{G}}$, respectively (Table 1). The second class contains one member that enhanced RME1-dependent $\beta$-galactosidase expression 100-fold (Table 1). This mutation was designated $\operatorname{RRE} \uparrow 4$, and corresponded to the base change $-2031^{\mathrm{G} \rightarrow \mathrm{A}}$.

The phenotypes of the RRE mutations in the RME1dependent activation assay suggested that we had identified an authentic RRE. It was not clear, however, whether these base pairs were also involved in RME1dependent repression of $I M E 1$. We replaced wild-type sequences with the RRE mutations upstream of the IME1 gene on plasmids to examine their effect on repression. IME1 expression was monitored by comparing sporulation in $\mathbf{a} / \mathbf{a}$ and $\mathbf{a} / \alpha$ ime $1 /$ ime 1 strains. The three RRE $\downarrow$ mutations each permitted increased levels of sporulation in the a/a diploid (Table 2, pAC136, pAC118-1, and pAC118-2). Thus, the RRE $\downarrow$ mutations cause elevated expression of the plasmid-borne IME1 gene (loss of repression) in the a/a strain. The RRE $\uparrow$ mutation did not permit increased levels of sporulation in the a/a diploid (Table 2, pAC118-3), indicating that repression was maintained. We conclude that these mutations lie in an RRE that is important for both RME1-dependent activation of the cyc1-lacZ reporter gene and RME1-dependent repression of $I M E 1$.

\section{Binding of RME1 to RRE-containing DNA}

We used a gel mobility retardation assay to test whether RMEl binds to DNA that contains the RRE. The probe was IME1 - 2146 to -2017 , the segment that caused RME1-dependent activation of the cyc1-lacZ reporter. One major complex was identified with an extract that contained RME1 (Fig. 6, lane 3). It was absent with extracts from rme1 $\Delta$ or $r m e 1-213$ strains (Fig. 6, lanes 2 and 4 , respectively|. We used an extract containing RME1 $\Delta 2$ 117 , a functional, truncated derivative to determine whether RMEl itself was present in the complex (Hope

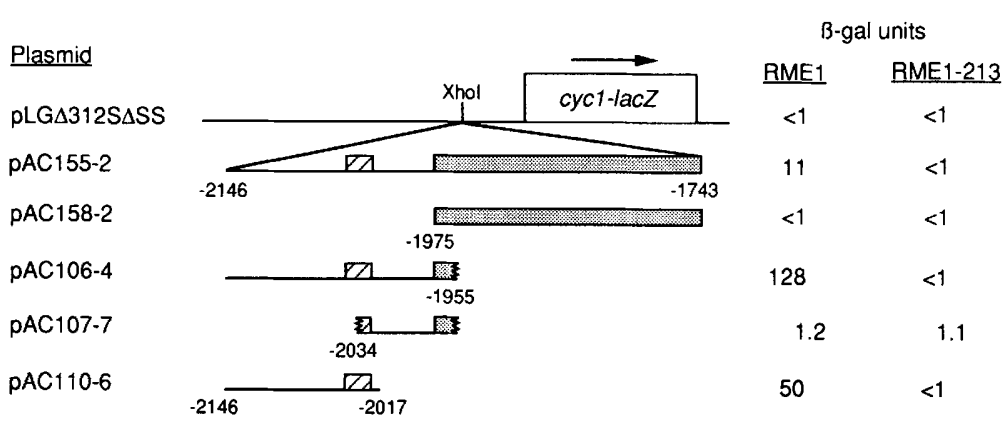

Figure 5. RME1-dependent activation. pLGA312S$\Delta S$ contains a $c y c 1-l a c Z$ gene that lacks UAS $_{C Y C 1}$ (not to scale). Derivatives contain insertions from the repression cassette. Strains, assays, and symbols were as described in the legend to Fig. 3. 
Table 1. Effects of RRE point mutations on RME1dependent activation

\begin{tabular}{llcc}
\hline & & \multicolumn{2}{c}{$\beta$-Galactosidase units } \\
\cline { 3 - 4 } Plasmid $^{\mathrm{b}}$ & Mutation (name) & RME1 & RME1-213 \\
\hline pAC119-10 & none (RRE) & $7.6^{\mathrm{c}}$ & 0.5 \\
pAC128-4 & $-2035^{\mathrm{T} \rightarrow \mathrm{G}}(\mathrm{RRE} \downarrow 1)$ & 0.7 & 0.5 \\
pAC119-1 & $-2033^{\mathrm{A} \rightarrow \mathrm{G}}(\mathrm{RRE} \downarrow 2)$ & 0.5 & 0.5 \\
pAC1 19-2 & $-2032^{\mathrm{A} \rightarrow \mathrm{G}}(\mathrm{RRE} \downarrow 3)$ & 0.7 & 0.7 \\
pAC1 19-3 & $-2031^{\mathrm{G} \rightarrow \mathrm{A}}(\mathrm{RRE} \uparrow 4)$ & 730 & 0.5 \\
\hline
\end{tabular}

${ }^{a}$ Constructs replaced UAS ${ }_{C Y C 1}$ in pKB112 with an IME1 - 2146 to -2017 segment containing the indicated mutation.

${ }^{\text {b }}$ Strains and assays were as described in the legend to Fig. 3. cDifferent absolute levels of RMEl-dependent $\beta$-galactosidase activity were observed here compared with insertions in pLG $\Delta 312 S \Delta S S$ (cf. pAC119-10 here with pACl10-6 in Fig. 5). The difference is likely attributable to the different polylinker sequences flanking the insertions.

and Struhl 1986). The truncated derivative formed a complex with greater mobility than that of the complex containing the full-length protein (Fig. 6, cf. lanes 3 and 6). An extract from a strain expressing both the fulllength and the truncated polypeptides yielded both complexes (Fig. 6, lane 5). These data indicate that RME1 binds to the -2146 to -2017 segment.

To determine the specificity of the RME1-DNA complex, we used a gel mobility retardation competition assay. Each binding reaction included wild-type labeled probe DNA $(-2146$ to -2017$)$ and various unlabeled competitor DNAs. DNA containing the RRE $\downarrow 1$, RRE $\downarrow 2$, or RRE $\downarrow 3$ mutation competed poorly compared with DNA containing the wild-type RRE (Fig. 7, lanes 3-7,10-16). DNA containing the RRE $\uparrow 4$ mutation competed more efficiently than DNA containing the wild-type sequence (Fig. 7, lanes 10-12,17,18; data not shown). These experiments demonstrate a correlation between the effects of the RRE mutations on the response to RME1 in vivo and on RME1-DNA complex formation in vitro: The RRE $\downarrow$ mutations block activation of the cyc1-lacZ reporter gene (Table 1), impair repression of IME1 (Table 2), and reduce the binding affinity for RME 1 protein (Fig. 7); the RRE $\uparrow$ mutation enhances activation of the cyc1-lacZ reporter and increases the affinity for RMEl protein.

Table 2. Effects of RRE point mutations on repression of IMEl

\begin{tabular}{llcc}
\hline & & \multicolumn{2}{c}{ Percent sporulation } \\
\cline { 3 - 4 } Plasmid $^{\mathrm{a}}$ & Mutation (name) & $\mathbf{a} / \mathbf{a}$ & $\mathbf{a} / \alpha$ \\
\hline pAC82 & none $(\mathrm{RRE})$ & 0.8 & 49 \\
pAC136 & $-2035^{\mathrm{T} \rightarrow \mathrm{G}}(\mathrm{RRE} \downarrow 1)$ & 11 & 52 \\
pAC118-1 & $-2033^{\mathrm{A} \rightarrow \mathrm{G}}(\mathrm{RRE} \downarrow 2)$ & 25 & 66 \\
pAC118-2 & $-2032^{\mathrm{A} \rightarrow \mathrm{G}}(\mathrm{RRE} \downarrow 3)$ & 15 & 43 \\
pAC118-3 & $-2031^{\mathrm{G} \rightarrow \mathrm{A}}(\mathrm{RRE} \uparrow 4)$ & 1 & 45 \\
\hline
\end{tabular}

aplasmids contained the indicated mutation upstream of IME1. ${ }^{\text {b }}$ Strains and assays were as described in the legend to Fig. 1.

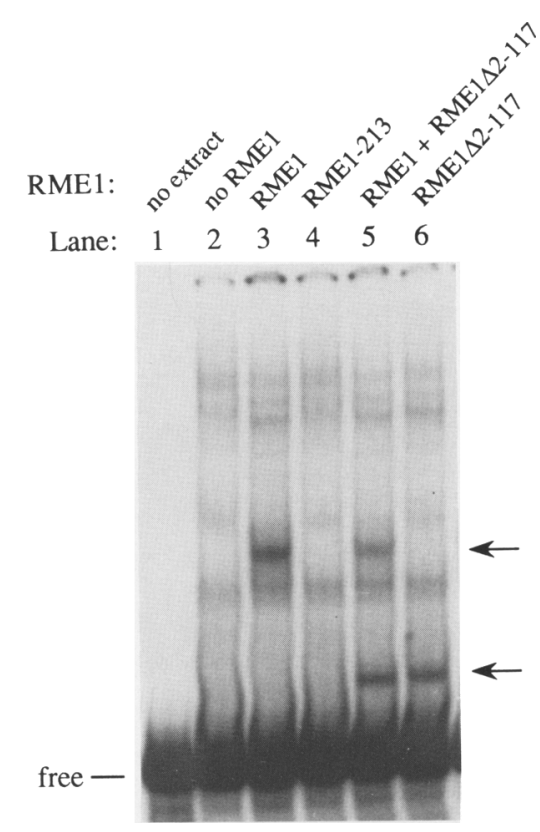

Figure 6. Gel mobility retardation assays with labeled IME1 -2146 to -2017 DNA and crude RMEl extracts. Probe was mixed with extract and then electrophoresed on a native $5 \%$ polyacrylamide gel. The RMEl derivatives present in each extract are indicated above the lane numbers. The upper arrow indicates the mobility of the RME1-DNA complex; the lower arrow indicates the mobility of the RME1 $\Delta 2-117-D N A$ complex. Extracts were from strains 930, 1043, 1073, 1174, and 1175.

\section{Further delineation of the RRE}

We defined more precisely the DNA responsible for binding RMEl by use of chemical nuclease footprinting. The probe contained IME1 - 2146 to -2017 and included the RRE $\uparrow 4$ mutation. This mutation increased the proportion of probe that was in the RMEl-DNA complex and thus facilitated isolation of the complex for footprinting. We observed a 21 -bp protected region corresponding to nucleotides -2044 to -2024 of IME1 (Fig. 8 ). This sequence includes the base pairs changed in all four of the RRE mutations (Fig. 4). We conclude that this 21-bp segment is included in the RME1-binding site.

To confirm that the DNA defined by nuclease protection is the RRE responsible for activity in vivo, we tested its ability to cause RME1-dependent repression of the CYC1 promoter. A synthetic oligonucleotide that contained the wild-type sequence from -2046 to -2022 (the protected region plus 2 flanking base pairs on each side) was inserted next to the modulation region up-

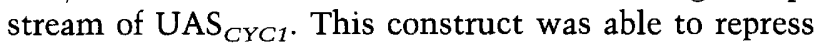
cyc1-lacZ expression fivefold when RME1 was expressed, whereas a construct that lacked the oligonucleotide insertion was unable to repress (Fig. 3, cf. pAC160-2 and pAC170-6). Insertion of two RREs gave a similar level of repression to that found with one element inserted (Fig. 3, pAC169-1 and pAC170-6). Thus this 25 -bp sequence, in conjunction with the modulation 

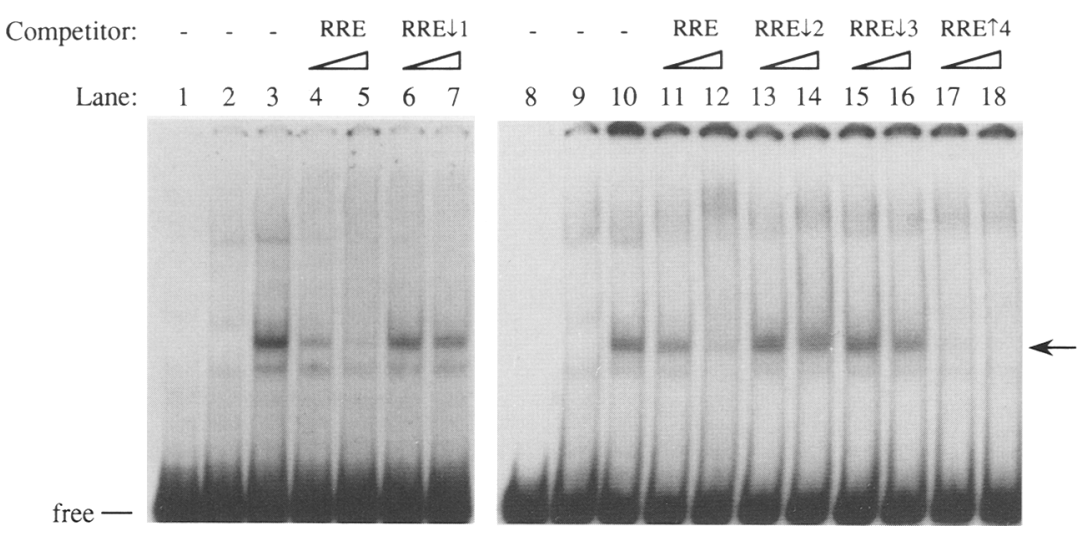

Figure 7. Competition of labeled RME1DNA complex formation with unlabeled DNA fragments. The labeled probe was IME1 - 2146 to -2017 . Binding reactions contained no extract (lanes 1,8); rmel $\Delta$ extract (lanes 2,9); RMEl extract (lanes 3-7,10-18). Excess unlabeled competitor [250-fold (lanes 4,6,11,13, $15,17)$ or 500 -fold (lanes $5,7,12,14,16,18)]$ was added to the binding reactions. Competitors were $I M E 1-2146$ to -2017 with wild-type (lanes 4-5,11-12) or mutant (lanes 6-7,13-18) RREs, as indicated above the lane numbers. The arrow indicates the mobility of the RME1-DNA complex. Extracts were from strains 930 and 1043. Lanes $1-7$ and 8-18 represent separate experiments. region, is sufficient for RMEl-dependent repression and contains a complete RRE.

All of our experiments thus far had been conducted on plasmids. To test the function of the RRE in its natural location, we examined the consequences of a chromosomal RRE deletion. The allele IME1-81 lacks the base pairs from -2044 to -2025 . We compared $I M E 1^{+}$and IME1-81 expression in a/ $\alpha$ diploids that differed in their expression of $R M E 1$ from the GAL1 promoter. Measurement of ime2-lac $Z$ expression and sporulation efficiency was used as assays (Table 3). Control strains that did not express RME1 gave high levels of $\beta$-galactosidase activity (508-619 units) and sporulation (82-90\%) when ho-

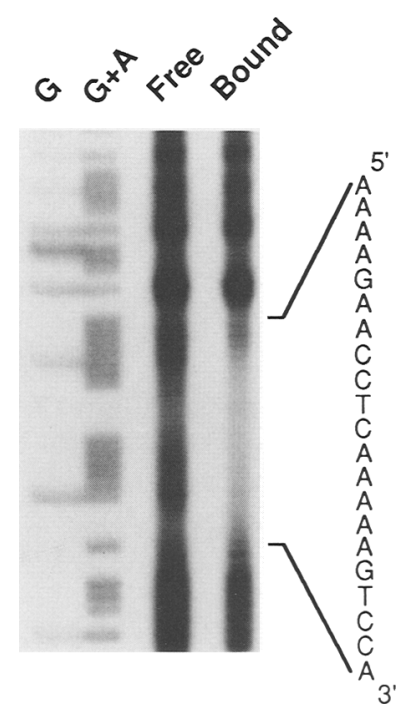

Figure 8. Chemical nuclease footprint of the RME1-DNA complex. The probe included IME1 -2146 to -2017 containing the RRE $\uparrow 4$ mutation and was labeled on the top strand. A preparative gel mobility retardation was used to separate free and bound probe. Gel slices were excised and treated with 1,10phenanthroline-copper ion reagent as described in Materials and methods. DNA was recovered and electrophoresed on an $8 \%$ sequencing gel. Maxam and Gilbert $\mathrm{G}$ and $\mathrm{G}+\mathrm{A}$ reactions were run as markers. The indicated nucleotide sequence is IME1 -2044 to -2024 with the RRE $\uparrow 4$ mutation. mozygous for either the $I M E 1^{+}$or the IME1-81 allele. A strain that expressed RME1 and was homozygous for the $I M E 1^{+}$allele gave only $2.7 \beta$-galactosidase units and $1.3 \%$ sporulation. A strain that expressed RMEl but was homozygous for the IME1-81 allele, however, produced 45 units of $\beta$-galactosidase activity and sporulated to $51 \%$ efficiency. We conclude that the deletion in IME181 removed sequences necessary for complete repression of the chromosomal IME1 gene by RME1.

\section{Discussion}

Our present studies provide the first direct information concerning the mechanism of RME1 action. We have shown that RME1 binds to a site upstream of IME1 that is required for repression and, furthermore, that the RME1-binding site and flanking region is sufficient to confer RMEl-dependent repression on a heterologous gene. These studies have extended our understanding of how the mating-type locus governs expression of meiotic genes: a1- $\alpha 2$ represses $R M E 1$ directly (Goutte and Johnson 1988; Covitz et al. 1991), and RME1 represses IME1 directly.

\section{Nature of the RRE}

The RRE is defined by its properties in vivo: It can support RME1-dependent activation of a reporter gene or (with the modulation region) repression of a heterologous promoter. It is required for repression of a plasmidborne IME1 gene, and it is essential for full RME1-de-

Table 3. Chromosomal deletion of the RRE

\begin{tabular}{lcccc}
\hline IME1 & RME1 & \multicolumn{2}{c}{$\beta$-gal units } & \\
\cline { 3 - 4 } genotype $^{\mathrm{a}}$ & \begin{tabular}{l} 
expression \\
\cline { 3 - 4 }
\end{tabular} & veg & spo & $\begin{array}{l}\text { Percent } \\
\text { sporulation }\end{array}$ \\
\hline$+/+$ & - & 5 & 508 & 90 \\
$81 / 81$ & - & 3.9 & 619 & 82 \\
$+/+$ & + & 0.6 & 2.7 & 1.3 \\
$81 / 81$ & + & 0.7 & 45 & 51
\end{tabular}

aStrains were 1285/1286, 1283/1282, 1285/1287, and 1283/1284.

bValues represent ime2-lacZ expression. 
pendent repression of the chromosomal IME1 gene. Our biochemical assays show that the RRE includes an RMEl-binding site that spans $21 \mathrm{bp}$.

Studies of the zinc finger proteins SP1 and Zif268 (Nardelli et al. 1991; Pavletich and Pabo 1991) suggest that a protein like RME1, with three zinc fingers, should bind to a 9-bp site. Why is the protected region in the RME1-dependent complex roughly twice this size? One explanation is that RME1 structural features lead to more extensive DNA contacts than for these other proteins. For example, the nonconsensus spacing between RME1 zinc fingers (Covitz et al. 1991) may result in a more elongated structure. A second explanation is that RME1 is a subunit of an oligomeric DNA-binding protein. We note that the protected region includes most of an imperfect direct repeat of the sequence $\mathrm{TCAA} /{ }^{\mathrm{A}} /$ $\left.{ }_{\mathrm{G}}\right) \mathrm{A}\left(\mathrm{G} /{ }_{\mathrm{A}}\right)\left({ }^{\mathrm{A}} / \mathrm{C}_{\mathrm{G}}\right)\left(\mathrm{A} /{ }_{\mathrm{T}}\right) \mathrm{CC}$, which we refer to as the RRE half-site. All three RRE $\downarrow$ mutations alter base pairs conserved by the two putative half-sites. In contrast, the RRE $\uparrow 4$ mutation, which improves binding, makes the downstream half-site more similar to the upstream halfsite. These mutational changes are consistent with the idea that the same polypeptide recognizes both halfsites. Our estimate of the size of RME1 in solution in crude extracts, based on gel filtration studies, is $70 \mathrm{kD}$, the size expected for a homodimer (P.A. Covitz, unpubl.). If RMEl bound as a homodimer, however, we would expect to find a novel gel mobility retardation complex in extracts containing both RME1 and RME1 $12-117$, representing a complex of the RRE, RME1, and RME1 2 2-117. The absence of this complex suggests that RMEl and RME1 $\Delta 2-117$ do not dimerize. This finding may indicate that RME1 $\Delta 2-117$ has an impaired ability to dimerize. Alternatively, RME1 may not bind as a homodimer but, rather, as part of a heteromeric complex. Experiments with purified RME1 should help to resolve this issue.

\section{Transcriptional activation by RME1}

We observed that RME1 can activate transcription from the RRE. Activation and repression by RME 1 may reflect alternate states or complexes, because activation is most efficient in the absence of the modulation region, whereas repression requires the modulation region. The ability of RME 1 to activate may result from the similarity of its amino terminus to an acidic activation domain (net charge of -7 for residues 1-100).

There are two indications that activation requires relatively efficient formation of the RME1-RRE complex. First, we have observed activation only when RMEl is overexpressed (from the $P_{G A L 1}-R M E 1$ gene). Second, activation is improved 100 -fold by the RRE $\uparrow 4$ mutation, which increases the efficiency of RME1-RRE complex formation in vitro. It is unlikely that the RRE $\uparrow 4$ mutation causes a qualitative change in the RME1-RRE complex because it is capable of directing repression of IME1. Experiments with Drosophila Krüppel have shown that its expression levels alone can determine whether it activates (high expression) or represses (low expression) (Sauer and Jäckle 1991). RME1 apparently has different properties, because its high-level expression permits both repression and activation. Thus, the ability of RME1 to activate or repress is determined by its expression levels as well as the context of the RRE.

These findings raise the question of whether RMEldependent activation has any biological significance. $I M E 1$ is activated only in a/ $\alpha$ cells, whereas $R M E 1$ is repressed in this cell type (Mitchell and Herskowitz 1986; Smith and Mitchell 1989). Furthermore, the RRE is not involved in the activation of IME1 by nutritional signals (see Fig. 2 and Table 3). Therefore, neither RME1 nor its binding site has a role in the activation of IME1. RME1 RNA levels, however, increase 10-fold after starvation in a or $\alpha$ haploid cells (P.A. Covitz, unpubl.). Thus, RME1 might activate a target gene not yet identified in starved haploid cells.

\section{The modulation region}

The 404-bp RME1 repression cassette includes functionally distinct upstream and downstream segments. The upstream segment $(-2146$ to -2017$)$ is necessary only to provide the $R R E$, because it may be functionally replaced by a synthetic RRE. The precise function of the downstream segment $(-1975$ to -1743$)$, the modulation region, is less clear. Deletions of either end of the modulation region destroy repression, suggesting either that there are multiple functional sites within the element or that precise spacing between the RRE and a second site is critical for repression. We note that the modulation region has potential binding sites for the silencer-binding proteins ABF1 $(-1874$ to -1859$)$ and RAP1 ( -1855 to -1847 ); each of these sites has a 1-bp deviation from the respective consensus (Ghosh 1992). Neither of these sites, however, is removed in any of the several deletions that abolish repression of UAS CYC1 $_{\text {. }}$ Clearly, a more systematic mutational analysis of the modulation region will be required to understand its functional requirements.

\section{Redundancy of RME1-dependent repression sites}

We have shown that DNA containing an RME1-binding site is essential for RME1-dependent repression of UAS $_{C Y C 1}$ by the repression cassette. This site, -2044 to -2024 , also contributes to repression of the chromosomal IME1 gene. Both assays of IME1 expressionsporulation and ime2-lacZ levels-however, indicate that the deletion allele IME1-81, which lacks the RRE, is still partially repressed by RME1. One explanation might be that RME1 has some affect on these assays that is independent of IME1. We found previously, however, that expression of IME1 from the GAL1 promoter renders sporulation and ime2-lacZ expression insensitive to RMEl (Covitz et al. 1991). Therefore, the incomplete constitutivity of the IME1-81 mutation must result from direct effects on IME1 expression. These observations suggest that RME1 is able to interact with the IME1 regulatory region through sites other than the -2044 to -2024 RRE. 
Where might additional RME1-binding sites lie? Existence of a far upstream site, near -3000 , was deduced from a previous study of fragments flanking IME1 that could titrate RME1 activity when present on multicopy plasmids (Granot et al. 1989). This putative site is not essential for repression, though, because we found that deletion of all sequences upstream of -2243 from a plasmid-borne IME1 gene did not relieve repression (Fig.1, cf. pAC55-2 and pAC82). On the basis of homology to the RRE half-site, we found a putative RME1-binding site within the IME1-coding region $(+111$ to +121$)$. Similarly, this putative half-site is not essential for repression because its deletion from the chromosome does not relieve repression (P.A. Covitz, unpubl.). These findings are consistent with the idea that there are multiple RME1-binding sites near IME1 with partially overlapping functions.

\section{Size of the IME1 regulatory region}

Most yeast genes have regulatory regions that extend 200-500 bp upstream of the coding region. Why should the IME1 regulatory region be so large? We believe that properties of the $H O$ gene, which has a $1.5-\mathrm{kb}$ regulatory region, may provide some insight. The $H O$ gene is regulated by multiple signals. Dissection of the $\mathrm{HO}$ upstream region has revealed separable sites that confer repression by al- $\alpha 2$, dependence on SWI4-SWI6, and restriction of expression to mother cells (for review, see Herskowitz 1989). IME1 also responds to several regulatory signals. IME1 expression depends on at least two pathways, one involving MCK1 and the other involving RIM1 (Neigeborn and Mitchell 1991; Su and Mitchell 1993). In addition, cAMP limitation causes elevated IME1 expression (Smith and Mitchell 1989; Matsuura et al. 1990) and appears to act independently of MCK1 and RIM1 (L. Neigeborn, pers. comm.). Regulation of IME1 by the mating-type locus also depends on at least two pathways, one involving $R M E 1$ and the other involving IME4 (Shah and Clancy 1992). Therefore, the long regulatory region of $I M E 1$ may also be useful for coordinating multiple regulatory signals.

\section{Materials and methods}

\section{Strains and RME1 alleles}

Yeast strains were all isogenic to SK-1 (Kane and Roth 1974); genotypes are listed in Table 4. Growth media were as described previously (Smith and Mitchell 1989). Strains used for Northern analyses, $\beta$-galactosidase assays, and protein extracts expressed $R M E 1$ derivatives from the GAL1 promoter. The $P_{G A L 1}-$ RME1 genes were integrated at one of two different loci: URA3 (ura3::P $\left.P_{G A L 1}-R M E 1:: U R A 3\right)$ or RME1 (rme1::P $P_{G A L 1}-$ $R M E 1:: T R P 1)$. Integration at URA3 was described previously (Covitz et al. 1991). The constructs at RME1 were created by one-step replacement of the native gene (Rothstein 1983) with $P_{G A L 1}-R M E 1$ and sequences from the integrating vector pRS304 (Sikorski and Hieter 1989), which contains the TRP1 marker. The $P_{\text {GAL1 }}-R M E 1$ derivatives used include $P_{G A L 1}-S 53-R M E 1$, which encodes a functional epitope-tagged derivative (Covitz et al. 1991); $P_{G A L 1}-S 53-r m e 1-213$, a nonfunctional mutant allele
Table 4. Yeast strains

\begin{tabular}{|c|c|}
\hline Strain & Genotype $^{\mathbf{a}}$ \\
\hline 805 & a arg6 his3 rme1-5::LEU2 ime1-13::HIS3 GAL80 \\
\hline 808 & $\alpha$ his3 ime1-13::HIS3 GAL80 \\
\hline 930 & a his4-G rme1-5::LEU2 pep4::URA3 \\
\hline 931 & a/a $\arg 4 / A R G 4$ his4-G/his4-N ade3/ADE3 \\
\hline 1043 & $\begin{array}{l}\text { a his4-G rme1-5::LEU2 ura3:: } P_{G A L 1}-S 53- \\
\text { RME1::URA3 pep4::URA3 }\end{array}$ \\
\hline 1049 & $\begin{array}{l}\alpha \text { arg6 his3 rme1-5::LEU2 ime1-13::HIS3 } \\
\text { ura3::P } P_{G A L 1}-S 53-R M E 1:: U R A 3\end{array}$ \\
\hline 1050 & $\begin{array}{l}\text { a arg6 his3 rme1-5::LEU2 ime1-13::HIS3 } \\
\text { ura3::P } P_{\text {GAL1 }}-S 53-R M E 1:: \text { URA3 }\end{array}$ \\
\hline 1051 & $\alpha$ his3 rme1-5::LEU2 ime1-13::HIS3 \\
\hline 1053 & a his3 rme1-5::LEU2 ime1-13::HIS3 GAL80 \\
\hline 1073 & $\begin{array}{l}\text { a his4-G rme1-5::LEU2 ura3::P } P_{G A L 1}-S 53- \\
\text { rme1-213::URA3 pep4::URA3 }\end{array}$ \\
\hline 1122 & a rme1::P $P_{G A L 1}-S 53-R M E 1:: T R P 1$ \\
\hline 1124 & $\alpha$ rme1::P $P_{G A L 1}-S 53-r m e 1-213:: T R P 1$ \\
\hline 1174 & $\begin{array}{l}\text { a his4-G rme1::P } \\
\text { ura3::P } P_{G A L 1}-R M E 1 \Delta 2-117: \text { URA3 pep4::URA3 }\end{array}$ \\
\hline 1175 & $\begin{array}{l}\text { a his4-G rme1-5::LEU2 ura3::P } P_{G A L 1}-R M E 1 \Delta 2 \text { - } \\
\text { 117:URA3 pep4::URA3 }\end{array}$ \\
\hline 1269 & $\begin{array}{l}\text { a his4-G rme1-5::LEU2 ura3::P } P_{G A L 1}-S 53- \\
\text { RME1::URA3 pep4::URA3 [pAC34] }\end{array}$ \\
\hline 1282 & a IME1-81 GAL80 \\
\hline 1283 & $\begin{array}{l}\alpha \text { his4-G rme1::P } \\
\text { ime2-4-1acZ::LEU2 }\end{array}$ \\
\hline 1284 & a $I M E 1-81$ \\
\hline 1285 & a ime2-4-1acZ::LEU2 \\
\hline 1286 & $\alpha$ his4-G rme1::P $P_{G A L 1}-S 53-R M E 1:: T R P 1$ GAL80 \\
\hline 1287 & $\alpha$ his4-G rme1::P $P_{G A L 1}-S 53-R M E 1:: T R P 1$ \\
\hline
\end{tabular}

${ }^{a}$ All strains have the additional alleles leu2 trp1 ura3 lys2 ho::LYS2 gal80::LEU2, except as indicated.

that encodes a Cys $\rightarrow$ Ser substitution at residue 213 in the second zinc finger motif (Covitz et al. 1991); and $P_{G A L 1^{-}}$ RME1 $\triangle 2-117$, described below.

$P_{G A L 1}-R M E 1 \Delta 2-117$ encodes a truncated derivative of RME1 that lacks residues 2-117 but retains the three carboxy-terminal zinc finger motifs. This gene was constructed by digesting plasmid pAM240 (Covitz et al. 1991) at the unique HindIII site in the vector and the BgIII site at codon 117 in RME1. The intervening DNA corresponding to the 5 ' end of the gene was eliminated, and the plasmid was recircularized with an oligonucleotide adapter containing HindIII and BglII sticky ends. The adapter was made by annealing the oligonucleotides 5 '-AGCTTATGCCCGGGGGA-3' (top strand) and 5'-GATCTCCCCCGGGCATA-3' (bottom strand). The resulting construct (pACA2-117) contained codons for the residues Met, Pro, and Gly fused in-frame to codons $118-300$ of RME1. This derivative was transferred on a HindIII-XhoI fragment into the HindIII and Sall sites of pBM272, which contains the GAL1 promoter (Johnston and Davis 1984); the resulting plasmid was called pAC12. $P_{G A L 1}-R M E 1 \triangle 2-117$ was transferred from pAC12 into YIp5 on an EcoRI partial digest fragment and integrated at $U R A 3$ by digestion with StuI and transformation into yeast. Integration of a single copy was confirmed by Southern analysis. $P_{G A L 1}-R M E 142-117$ blocked expression of an ime2-lac $Z$ fusion in haploid strains that contained a deletion of the native $R M E 1$ gene. Therefore $P_{G A L 1}-R M E 1 \triangle 2-117$ is a functional derivative.

All strains used for protein extraction contained a disruption in the PEP4 protease gene, created by transformation of the 
pep4::URA3 disruption plasmid pTS15 (Rothman et al. 1986), digested with EcoRI and XhoI, and confirmed by Southern analysis.

\section{IME1 isolation and deletions}

Our original IME1 clone was isolated through a selection for high-copy plasmids that bypassed RME1 activity (Smith and Mitchell 1989). This strategy raised the concern that our clone may have acquired a mutation that relieved repression by RME1. To avoid such a complication, we used a nonselective screen to obtain plasmid pAC55-2, the source of $I M E 1$ for the present studies. The IME1 gene on pAC55-2 was isolated from the SK-1 yeast genetic background by colony hybridization in bacteria. An SK-1 library was generated from genomic DNA partially digested with Sau3A and ligated into the BamHI site of the low-copy shuttle vector pRS314 (Sikorski and Hieter 1989). A $2.3 \mathrm{Bg}$ III fragment from pAM500 [which contains the previously isolated IME1 gene [Smith and Mitchell 1989)] was used as a probe. DNA from a single positive colony was purified, and the plasmid was found to contain an $8.6-\mathrm{kb}$ insert. Identity of the IME1 gene on the insert was confirmed by (1) comparison of restriction digest patterns of pAC55-2 and pAM500; (2) partial sequencing of the IME1-coding region on pAC55-2; and $|3|$ genetic complementation of an ime1 deletion (see Fig. 1). The derivatives of pAC55-2 shown in Figure 1 were constructed by deleting DNA between restriction sites or by digesting with exonclease III and S1 nucleases. The Sequenase-dideoxy method (U.S. Biochemicals) was used to sequence the top strand of IME1 from -2243 to -1078 . This provided 44 bp of overlap with the upstream end of the previously published sequence (Smith et al. 1990). The bottom strand was sequenced on an Applied Biosystems 373A automated sequencer.

Subclones of the upstream regulatory locus were generated by PCR amplification and ligated into the KpnI site upstream of $\mathrm{UAS}_{C Y C 1}$ in pKB112 [a derivative of pLG $312 \mathrm{~S}$ /Guarente and Mason 1983; Bowdish and Mitchell 1993)l, the Xhol site upstream of pLG $\Delta 312 S \Delta S S$ (Guarente and Mason 1983), or into a pBluescript II vector (Stratagene). The fidelity of all PCR-generated clones was confirmed by sequencing. One of these constructs, pACl 16-3, contained IME1 $(-2146$ to -2017$)$ in pBluescript II and was used as an intermediate for other constructions described below.

The IME1-81 deletion allele was created by directed mutagenesis of pAC82 using the bottom strand oligonucleotide 5'-CATTTACTGCCATTTAGTCGACATCCGCATTCTTG-3', which removed -2044 to -2025 and inserted one C (underlined) to create a Sall restriction site. The region containing the mutation was cloned into the integrating vector pRS306 (Sikorski and Hieter 1989) to give pAC156. pAC156 was used to transform yeast in a two-step replacement that created IME1-81 in the chromosome. This allele is marked with only the SalI site, which was used to follow the mutation in genetic crosses.

\section{RRE mutant isolation}

RRE mutations were generated by mutagenic PCR amplification of pAC116-3 (Leung et al. 1989). Flanking KpnI and SalI sites derived from the polylinker were digested, and the products were ligated into the KpnI and SalI sites of pKB112, which eliminates $\mathrm{UAS}_{\mathrm{CYCI}}$ sequences and gives inserts in a single orientation. Thus, a pool of plasmids with mutated inserts was collected. pAC119-10, the wild-type positive control, was made by ligating the wild-type fragment from pACl16-3 into the KpnI and Sall sites of pKB112.

The mutant plasmid pool was amplified in Escherichia coli and transformed into yeast strain 1122. Transformants were replica plated onto selective galactose medium containing $\mathrm{X}$-gal. Colony color was compared with that of colonies bearing the control plasmid pAC119-10. Plasmids from white colonies were retrieved in $E$. coli and retested in yeast strain 1122 . The inserts from 38 clones were sequenced and found to contain one to six mutations including transitions, transversions, and deletions. Thirty contained at least one mutation in the RRE region. Two of the most frequently isolated transitions and one transversion were introduced singly by oligo-directed mutagenesis of pAC116-3. These mutant elements were then cloned into the KpnI and SalI sites of pKB112 to form pAC128-4, pAC119-1, and pAC119-2, which contain the RRE $\downarrow 1, \operatorname{RRE} \downarrow 2$, and RRE $\downarrow 3$ mutations, respectively. A transition not isolated previously, designated $\operatorname{RRE} \uparrow 4$, was introduced in pAC116-3 and similarly transferred to pKB112 to form pAC119-3. RRE $\downarrow 1, \mathrm{RRE} \downarrow 2$, RRE $\downarrow 3$, and RRE $\uparrow 4$ were introduced separately by oligo-directed mutagenesis of pAC82 to their normal positions upstream of the plasmid IME1 gene, thus forming pAC136, pACl18-1, pAC118-2, and pAC118-3, respectively.

\section{Northern analysis}

IME1 RNA expression from pAC82 and pAC85-26 was assayed in strains grown to early log phase in synthetic acetate-glycerol media lacking tryptophan and shifted to $2 \%$ potassium acetate plus auxotrophic amino acid supplements. RNA was prepared at 0,2 , and $4 \mathrm{hr}$ after the shift. Electrophoresis, blotting, and hybridization conditions were as described previously (Smith and Mitchell 1989).

\section{$\beta$-Galactosidase and sporulation assays}

Assays of strains 1122 and 1124 bearing derivatives of the cyc1lacZ reporter plasmids pKB112 or pLG $\Delta 312 S \Delta S S$ were performed on cells grown in synthetic galactose media lacking uracil to mid-log phase. ime2-lacZ expression, used to monitor IME1 regulation (Smith et al. 1990), was assayed from cells grown to log phase in YEPAc (veg) and shifted to $2 \%$ potassium acetate plus auxotrophic supplements [spo]. Percent sporulation was measured by counting the number of asci per 200 cells after 2-3 days on sporulation medium. The reported values of all $\beta$-galactosidase and sporulation assays are the average of three determinations.

\section{Protein extracts}

Cells were grown in $500 \mathrm{ml}$ of YEPAc media to late log phase, harvested by centrifugation, washed once in $\mathrm{H}_{2} \mathrm{O}$ and once in lysis buffer $\left[200 \mathrm{~mm}\right.$ Tris- $\mathrm{H}_{2} \mathrm{SO}_{4}$ at $\mathrm{pH} 7.9,50 \mathrm{mM}\left(\mathrm{NH}_{4}\right)_{2} \mathrm{SO}_{4}, 2$ $\mathrm{mM} \mathrm{ZnSO}_{4}, 1 \mathrm{~mm}$ EDTA, $7 \mathrm{~mm} \beta$-mercaptoethanol, $10 \%$ glycerol (vol/vol)]. All subsequent steps were performed on ice or at $4^{\circ} \mathrm{C}$. Pellets were resuspended in $4 \mathrm{ml}$ of lysis buffer with protease inhibitors $(100 \mu \mathrm{M}$ PMSF, $1 \mu \mathrm{g} / \mathrm{ml}$ of aprotinin, $0.5 \mu \mathrm{g} / \mathrm{ml}$ of leupeptin, $0.7 \mu \mathrm{g} / \mathrm{ml}$ of pepstatin) and $3 \mathrm{ml}$ of acid-washed glass beads. Cells were broken by 20 -sec pulses of vortexing for a total of 4-5 min. Debris was removed by centrifugation at $10,000 \mathrm{~g}$ for $15 \mathrm{~min}$, and the supernatant was then centrifuged at $106,000 \mathrm{~g}$ for $1 \mathrm{hr}$ to remove insoluble material. Polyethylenimine ( $\mathrm{pH} 7.6)$ was added to the supernatant to a final concentration of $0.08 \%$ (vol/vol). Precipitated nucleic acid was removed by centrifugation at $10,000 \mathrm{~g}$ for $10 \mathrm{~min}$. Solid $(\mathrm{NH} 4)_{2} \mathrm{SO}_{4}$ $(0.35$ grams $/ \mathrm{ml}$ ) of supernatant was added and dissolved slowly for $1 \mathrm{hr}$. Precipitated protein was collected by centrifugation at $10,000 \mathrm{~g}$ for $20 \mathrm{~min}$. Pellets were dissolved in storage buffer [50 $\mathrm{mm}$ Tris- $\mathrm{HCl}$ at $\mathrm{pH} 7.9,50 \mathrm{~mm} \mathrm{KCl}, 1 \mathrm{~mm} \mathrm{DTT}, 25 \%$ (vol/vol) 
glycerol] with protease inhibitors and dialyzed against storage buffer with $100 \mu \mathrm{M}$ PMSF. Precipitated material was removed from the dialysate by centrifugation at $10,000 \mathrm{~g}$ for $15 \mathrm{~min}$. Extracts were adjusted to a concentration of $15 \mathrm{mg} / \mathrm{ml}$ of protein in storage buffer with protease inhibitors. Aliquots were frozen in a dry ice/ethanol bath, stored at $-70^{\circ} \mathrm{C}$, and thawed only once. The samples retained DNA-binding activity for up to 3 weeks.

\section{Gel mobility retardation assays}

The probe for mobility retardation assays was generated by filling in $5^{\prime}$ overhangs of digested PCR products with $\left[\alpha^{-{ }^{32}} \mathrm{P}\right] \mathrm{dATP}$ and Klenow enzyme. The DNA included $130 \mathrm{bp}$ of IME1 DNA $(-2146$ to -2017$)$ and $10 \mathrm{bp}$ of flanking polylinker sequence. Binding reactions contained $16 \mu]$ of retardation buffer $[50 \mathrm{mM}$ Tris- $\mathrm{HCl}(\mathrm{pH} 7.9) 50 \mathrm{~mm} \mathrm{KCl}, 0.5 \mathrm{~mm} \mathrm{MgCl}_{2}, 250 \mu \mathrm{g} / \mathrm{ml}$ of BSA, $1.5 \mathrm{~mm}$ DTT, $12 \%$ (vol/vol) glycerol], $1 \mu \mathrm{g}$ of poly[d(I-C)], $1 \mu \mathrm{g}$ of pBluescript II DNA, $0.25 \mathrm{ng}(20,000 \mathrm{cpm})$ of radiolabeled probe, and $30 \mu \mathrm{g}$ of protein extract in a final volume of $20 \mu \mathrm{l}$. For competition reactions retardation buffer volume was reduced to $15 \mu \mathrm{l}$, and 250- or 500-fold excess of cold competitor in $1 \mu \mathrm{l}$ was added. Protein extract was added last in all reactions. Mixtures were incubated for $25 \mathrm{~min}$ at room temperature and loaded onto a prerun $5 \%$ polyacrylamide gel $(29: 1$ acrylamide/bis $\}$ containing $2.5 \%$ glycerol (vol/vol), buffered with $0.5 \times$ TBE. Samples were electrophoresed at $25 \mathrm{~mA}$ in $0.5 \times$ TBE. Gels were dried and exposed to film overnight with an intensifying screen at $-70^{\circ} \mathrm{C}$.

\section{Chemical nuclease footprinting}

The source of the probe for the nuclease protection assay was pAC117-3, a site-directed mutant derivative of pAC116-3 that contains the $\operatorname{RRE} \uparrow 4-2031^{\mathrm{G} \rightarrow \mathrm{A}}$ mutation. A 210-bp fragment single end-labeled on the top strand was purified from digested pAC117-3 DNA. The probe included 130 bp of IME1 DNA $(-2146$ to -2017 with RRE $\uparrow 4)$ and 80 bp of polylinker sequence. In a scaled-up gel mobility retardation, $300 \mu \mathrm{g}$ of protein extract from strain 1269 [which carries $P_{G A L 1}-R M E 1$ on the low-copy plasmid pAC34 (Covitz et al. 1991), as well as having a chromosomal copy] was added to $160 \mu$ l of retardation buffer, $10 \mu \mathrm{g}$ poly[d(I-C)], $10 \mu \mathrm{g}$ of pBluescript II, and $400,000 \mathrm{cpm}$ of probe DNA in a final volume of $200 \mu \mathrm{l}$. Samples were incubated and electrophoresed as described above. The gel was wrapped in plastic and exposed to film without drying. Gel slices containing free probe DNA or RME1-DNA complex were cut out and placed in $5 \mathrm{ml}$ of $10 \mathrm{~mm}$ Tris- $\mathrm{HCl}(\mathrm{pH} 8.0)$. Next, $0.5 \mathrm{ml}$ of 1,10-phenanthroline-copper ion reagent $[5 \% 9 \mathrm{~mm} \mathrm{CuSO}, 5 \%$ $40 \mathrm{mM}$ 1,10-phenanthroline in ethanol, $90 \% \mathrm{H}_{2} \mathrm{O}$ (vol/vol)] was added, followed by $0.5 \mathrm{ml}$ of $0.5 \%$ mercaptoproprionic acid $(\mathrm{Ku}-$ wabara and Sigman 1987). The reaction proceeded for $30 \mathrm{~min}$ and was then quenched by adding $0.5 \mathrm{ml}$ of 2,9-dimethyl-1,10phenanthroline $(5.8 \mathrm{mg} / \mathrm{ml}$ in ethanol). The gel slices were rinsed with water and placed in dialysis bags, each with $0.4 \mathrm{ml}$ of TBE buffer. The DNA was electroeluted for $2 \mathrm{hr}$ at $70 \mathrm{~V}$, polarity was reversed for $2 \mathrm{~min}$, and the liquid was recovered from the bags. After one phenol-chloroform-isoamyl alcohol extraction $(25: 24: 1) 1 \mu \mathrm{g}$ carrier tRNA was added, and the samples were precipitated with ethanol. The pellets were rinsed with $80 \%$ ethanol and dried, and activity was determined by Cerenkov counting. Samples were dissolved in Maxam-Gilbert loading buffer (Maxam and Gilbert 1980), heated to $90^{\circ} \mathrm{C}$ for 5 min, and run on an $8 \%$ sequencing gel $(31,000 \mathrm{cpm}$ per lane $)$. Maxam-Gilbert $G$ and $G+A$ reactions were run simultaneously as markers (Maxam and Gilbert 1980).

\section{Acknowledgments}

We thank M. Carlson, D. Shore, and members of the Mitchell laboratory for helpful comments on the manuscript. This work was supported by U.S. Public Health Service grant GM3951, the Irma T. Hirschl Charitable Trust, and the The Chicago Community Trust/Searle Scholars Program. P.A.C. was supported by U.S. Public Health Service training grants T32AI07161 and T32CA09503.

The publication costs of this article were defrayed in part by payment of page charges. This article must therefore be hereby marked "advertisement" in accordance with 18 USC section 1734 solely to indicate this fact.

\section{Note added in proof}

The updated IME1 sequence has been submitted to the GenBank data library under accession number M37188.

\section{References}

Bowdish, K.S. and A.P. Mitchell. 1993. Bipartite structure of an early meiotic upstream activation sequence from Saccharomyces cerevisiae. Mol. Cell. Biol. 4: 2172-2181.

Buchman, A.R., W.J. Kimmerly, J. Rine, and R.D. Kornberg. 1988. Two DNA-binding factors recognize specific sequences at silencers, upstream activating sequences, autonomously replicating sequences, and telomeres in Saccharomyces cerevisiae. Mol. Cell. Biol. 8: 210-225.

Brand, A.H., G. Micklem, and K.A. Nasmyth. 1987. A yeast silencer contains sequences that can promote autonomous plasmid replication and transcriptional activation. Cell 51: 709-719.

Covitz, P.A., I. Herskowitz, and A. P. Mitchell. 1991. The yeast RMEl gene encodes a putative zinc finger protein that is directly repressed by a1- $\alpha 2$. Genes \& Dev. 5: 1982-1989.

Engebrecht, J. and G.S. Roeder. 1990. MER1, a yeast gene required for chromosome pairing and genetic recombination, is induced in meiosis. Mol. Cell. Biol. 10: 2379-2389.

Ghosh, D. 1992. Transcription factor recognition sites, release 4.0. In Program manual for the GCG package, Version 7, Data reference set, vol. 3, pp. 49-73, Genetics Computer Group, Inc., Madison, WI.

Goutte, C. and A.D. Johnson. 1988. al protein alters the DNA binding specificity of $\alpha 2$ repressor. Cell 52: 875-882.

Granot, D., J.P. Margolskee, and G. Simchen. 1989. A long upstream region of the IME1 gene regulates meiosis in yeast. Mol. Gen. Genet. 218: 308-314.

Guarente, L. and T. Mason. 1983. Heme regulates transcription of the CYC1 gene of Saccharomyces cerevisiae via an upstream activation site. Cell 32: 1279-1286.

Herskowitz, I. 1989. A regulatory hierarchy for cell specialization in yeast. Nature 342: 749-757.

Hope, I.A. and K. Struhl. 1986. Functional dissection of a eukaryotic transcriptional activator protein, GCN4 of yeast. Cell 46: 885-894.

Johnson, A.D. and I. Herskowitz. 1985. A repressor (MATa2 product) and its operator control expression of a set of cell type specific genes in yeast. Cell 42: 237-247.

Johnston, M. and R.W. Davis. 1984. Sequences that regulate the divergent GAL1-GAL10 promoter in Saccharomyces cerevisiae. Mol. Cell. Biol. 4: 1440-1448.

Kane, S.M. and R. Roth. 1990. Carbohydrate metabolism during ascospore development in yeast. J. Bacteriol. 118: 8-14.

Kassir, Y. and G. Simchen. 1976. Regulation of mating and mei- 
osis in yeast by the mating type locus. Genetics 82: 187-206.

Kassir, Y., D. Granot, and G. Simchen. 1988. IME1, a positive regulator gene of meiosis in Saccharomyces cerevisiae. Cell 52: 853-862.

Kayne, P.S., U.J. Kim, M. Han, J.R. Mullen, F. Yoshizaki, and M. Grunstein. 1988. Extremely conserved histone H4 N terminus is dispensable for growth but essential for repressing the silent mating loci in yeast. Cell 55: 27-29.

Keleher, C.A., C. Goutte, and A.D. Johnson. 1988. The yeast cell-type-specific repressor $\alpha 2$ acts cooperatively with a noncell-type-specific protein. Cell 53: 927-936.

Keleher, C.A., M.J. Redd, J. Schultz, M. Carlson, and A.D. Johnson. 1992. Ssn6-Tupl is a general repressor of transcription in yeast. Cell 68: 709-719.

Kuwabara, M. and D. Sigman. 1987. Footprinting DNA-protein complexes in situ following gel retardation assays using 1,10 phenanthroline-copper ion: Escherichia coli RNA polymerase-lac promoter complexes. Biochemistry 26: 7234-7238.

Leung, D.W., E. Chen, and D.V. Goeddel. 1989. A method for random mutagenesis of a defined DNA segment using a modified polymerase chain reaction. Technique 1: 11-15.

Matsuura, A., M. Treinin, H. Mitsuzawa, Y. Kassir, I. Uno, and G. Simchen. 1990. The adenylate cyclase/protein kinase cascade regulates entry into meiosis in Saccharomyces cerevisiae through the gene IME1. EMBO I. 9: 3225-3232.

Maxam, A.M. and W. Gilbert. 1980. Sequencing end-labeled DNA with base-specific chemical cleavages. Methods Enzymol. 65: 499-560.

Mitchell, A.P. and I. Herskowitz. 1986. Activation of meiosis and sporulation by repression of the RME1 product in yeast. Nature 319: 738-742.

Mitchell, A.P., S.E. Driscoll, and H.E. Smith. 1990. Positive control of sporulation-specific genes by the IME1 and IME2 products in Saccharomyces cerevisiae. Mol. Cell. Biol. 10: 2104-2110.

Nardelli, J., T.J. Gibson, C. Vesque, and P. Charnay. 1991. Base sequence discrimination by zinc finger DNA-binding domains. Nature 349: 175-178.

Nasmyth, K.A. 1982. The regulation of yeast mating-type chromatin structure by SIR: An action at a distance affecting both transcription and transposition. Cell 30: 567-578.

Neigeborn, L. and A.P. Mitchell. 1991. The yeast MCK1 gene encodes a protein kinase homolog that activates early meiotic gene expression. Genes \& Dev. 5: 533-548.

Pavletich, N.P. and C.O. Pabo. 1991. Zinc finger-DNA recognition: Crystal structure of a Zif268-DNA complex at $2.1 \AA$. Science 252: 809-817.

Roth, S.Y., M. Shimizu, L. Johnson, M. Grunstein, and R.T. Simpson. 1992. Stable nucleosome positioning and complete repression by the yeast $\alpha 2$ repressor are disrupted by aminoterminal mutations in histone H4. Genes \& Dev. 6: 411-25.

Rothman, J.H., C.P. Hunter, L.A. Valls, and T.H. Stevens. 1986. Overproduction-induced mislocalization of a yeast vacuolar protein allows isolation of its structural gene. Proc. Natl. Acad. Sci. 83: 3248-3252.

Rothstein, R. 1983. One step gene disruption in yeast. Methods Enzymol. 101: 202-211.

Sauer, F. and H. Jäckle. 1991. Concentration-dependent transcriptional activation or repression by Krüppel from a single binding site. Nature 353: 563-566.

Schnell, R.A. and J. Rine. 1986. A position effect on the expression of a tRNA gene mediated by the SIR genes in Saccharomyces cerevisiae. Mol. Cell. Biol. 6: 494-501.

Shah, J.C. and M.J. Clancy. 1992. IME4, a gene that mediates MAT and nutritional control of meiosis in Saccharomyces cerevisiae. Mol. Cell. Biol. 12: 1078-1086.
Sherman, A., M. Shefer, S. Sagee, and Y. Kassir. 1993. Posttranscriptional regulation of IMEl determines initiation of meiosis in Saccharomyces cerevisiae. Mol. Gen. Genet. 237: 375-384.

Shimizu, M., S.Y. Roth, C. Szent-Gyorgyi, and R.T. Simpson. 1991. Nucleosomes are positioned with base pair precision adjacent to the $\alpha 2$ operator in Saccharomyces cerevisiae. EMBO I. 10: 3033-3041.

Shore, D. and K.A. Nasmyth. 1987. Purification of a DNA-binding protein from yeast that binds to both silencer and activator elements. Cell 51: 721-732.

Shore, D., D.J. Stillman, A.H. Brand, and K.A. Nasmyth. 1987. Identification of silencer binding proteins from yeast: Possible roles in SIR control and DNA replication. EMBO $J$. 6: $461-467$.

Sikorski, R.S. and P. Hieter. 1989. A system of shuttle vectors and yeast host strains designed for efficient manipulation of DNA in Saccharomyces cerevisiae. Genetics 122: 19-27.

Singh, J. and A.J. Klar. 1992. Active genes in budding yeast display enhanced in vivo accessibility to foreign DNA methylases: A novel in vivo probe for chromatin structure of yeast. Genes \& Dev. 6: 189-196.

Smith, H.E. and A.P. Mitchell. 1989. A transcriptional cascade governs entry into meiosis in yeast. Mol. Cell. Biol. 9: 21422152.

Smith, H.E., S.S.Y. Su, L. Neigeborn, S.E. Driscoll, and A.P. Mitchell. 1990. Role of IME1 expression in control of meiosis in Saccharomyces cerevisiae. Mol. Cell. Biol. 10: 61036113.

Strathern, J.N., A.J.S. Klar, J.B. Hicks, J.A. Abraham, J.M. Ivy, K.A. Nasmyth, and C. McGill. 1982. Homothallic switching of yeast mating type cassettes is initiated by a doublestranded cut in the MAT locus. Cell 31: 183-192.

Su, S.S.Y. and A.P. Mitchell. 1993. Identification of functionally related genes that stimulate early meiotic gene expression in yeast. Genetics 133: 67-77.

Sussel, L. and D. Shore. 1991. Separation of transcriptional activation and silencing functions of the RAP1-encoded repressor/activator protein 1: Isolation of viable mutants affecting both silencing and telomere length. Proc. Natl. Acad. Sci. 88: 7749-7753.

Zhang, M., V.L.S. Rosenblum, C.V. Lowry, K.A. Boakye, and R.S. Zitomer. 1991. A yeast protein with homology to the beta-subunit of $\mathrm{G}$ proteins is involved in control of hemeregulated and catabolite-repressed genes. Gene 97: 153-161.

Zitomer, R.S. and C.V. Lowry. 1992. Regulation of gene expression by oxygen in Saccharomyces cerevisiae. Microbiol. Rev. 56: 1-11. 


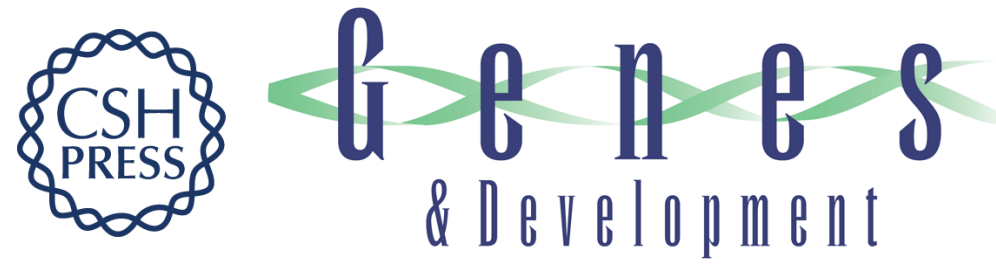

\section{Repression by the yeast meiotic inhibitor RME1.}

P A Covitz and A P Mitchell

Genes Dev. 1993, 7:

Access the most recent version at doi:10.1101/gad.7.8.1598 $\begin{array}{ll}\text { References } & \begin{array}{l}\text { This article cites } 47 \text { articles, } 17 \text { of which can be accessed free at: } \\ \text { http://genesdev.cshlp.org/content/7/8/1598.full.html\#ref-list-1 }\end{array}\end{array}$

License

Email Alerting

Receive free email alerts when new articles cite this article - sign up in the box at the top Service right corner of the article or click here.

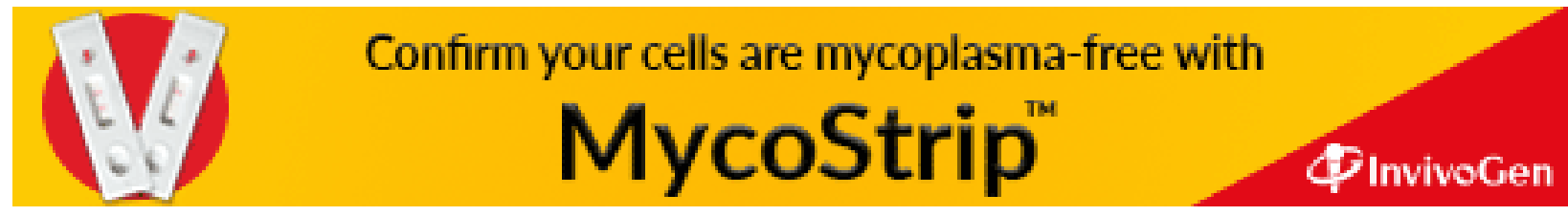

